\title{
ACCEPTABILITY OF BREAD PRODUCED FROM HAUSA-POTATO AND SWEETPOTATO COMPOSITE FLOURS
}

\author{
*ANIEDU, C. AND AGUGO, U.A. \\ National Root Crops Research Institute (NRCRI), Umudike, \\ PMB 7006, Umuahia, Abia State, Nigeria. \\ *Corresponding author. Email: canonaniedu@yahoo.com
}

\begin{abstract}
This study was conducted to compare the quality of bread produced from Hausa potato (HP) flour and sweetpotato (SP) flour at different substitution levels with wheat flour. The proximate analysis and sensory evaluation of the bread samples were determined. The proximate composition analysis revealed that the parameters such as crude fiber, ether extract and ash of the samples increased with an increase in the proportion. Higher fiber content was observed in Hausa potato bread samples, with the $30 \%$ substitution level of HPB recording the highest fiber content of 3.5\%. The protein content of all the samples from HP, SP and WH ranges from 2.6 to 6.8\%, highest protein was observed in WH bread sample. There was no significant differences ( $p<0.05)$ among $W H$ and $H P$ samples at $10 \%$ substitution levels in all the sensory attributes evaluated (colour, taste, texture and general acceptability). However, it was observed that sweetpotato flour could act as a colouring agent in bread production in bread production. All the same, wheat bread sample had highest mean scores in all the sensory attributes evaluated.
\end{abstract}

Keywords: Hausa potato (PH), sweetpotato (SP), wheat (WH), bread (B)

\section{INTRODUCTION}

Bread is an important staple food, the consumption of which is becoming steady even in the rural areas in Nigeria. It is however, relatively expensive, being made from imported wheat that is not cultivated in the tropics (Edema et al, 2005). The report of Olaye et al, (2006) observed that, efforts have been made to promote the use of composite flours in which flour from locally grown crops replace a portion of wheat flour in bread production. The purpose is to reduce the quantity of imported wheat flour and increase the use of locally made flours in bread production. This will further help, in diversifying the use of both widely known and other unfamiliar locally available crops.

Hausa-potato (Solenostenemon rotundifolius) (Poir) J.K Morton, is believed to have originated in the savannah region between Togo and Guinea (Harlen et al, 1976) and spread throughout tropical Africa. The plants are small, usually about $20-30 \mathrm{~cm}$ high. Although the Hausa-potato is not a widely cultivated food crop in Africa, it is still popular in a few places, such as the Jos plateau areas of Nigeria where it is called tumuku (Allemann and Coertze, 1997) The tubers can be used as a potato substitute and are usually cooked in a curry and eaten with rice, they can also be boiled, baked or fried (Karuna et al, 2000). Sweetpotato (Ipomea batatas) is a temperate crop but which is also grown in the tropics. The roots of sweetpotato are also important to man as foods. Sweetpotato is a popular food in Nigeria. It ranks next to the cereal grains as the major source of carbohydrate and provide a significant part of the total food supply to people of the tropics (Onimawo and Egbekun, 1998). Sweetpotato, like most other root crops is poor in protein but fair in their supply of Bvitamins, the cultivar with yellowish flesh is particularly rich in ascorbic acid (Rowland, 1993). Sweetpotato produced in Africa is consumed by boiling, frying or roasting the tubers. However, Aniedu and Oti, (2007), produced various confectioneries and non-confectionery 
foods from sweetpotato. Furthermore the report stated that $10 \%$ sweet potato flour can be used as complement to wheat flour in bread production.

\section{MATERIALS AND METHODS}

The Hausa-potato and sweetpotato roots used for the study were obtained from Other Root Crops and Sweetpotato Programmes of National Root Crops Research Institute (NRCRI) Umudike respectively. The wheat flour used in the preparation of the control sample was purchased from Umuahia main market in Abia State of Nigeria.

Processing of Hausa-potato and Sweetpotato - The roots were processed into flour, using the method described by Aniedu and Oti, (2007) in production of sweetpotato flour in figures 1and 2. Hausa-potato and sweetpotato roots were harvested, peeled, washed thoroughly and sliced to about 1 to $2 \mathrm{~mm}$ thickness using a manual slicing instrument. The slices were then spread out on (black polythene covered) raised platform (to guard against contamination), in a very clean environment, and allowed to sun-dry. The drying was completed on the second day under hot sun, so that the growth of mould was not possible. The dried slices were milled into powder and screened through a $0.25 \mathrm{~mm}$ sieve to produce the flours.

Blend formation - Flour blends of (HP) and (SP) were prepared by mixing with wheat flours in the proportions of 70:30, 80:20, and 90:10 respectively using machine food processor (Kenwood km 201, England).

Baking process - The six blended formulations and control, made from $100 \%$ wheat flour were baked in separate bread pans in the oven. The method of bread production was as described by Aniedu and Oti, (2007).

Processing of Hausa-potato flour

Fresh Hausa-potato Roots

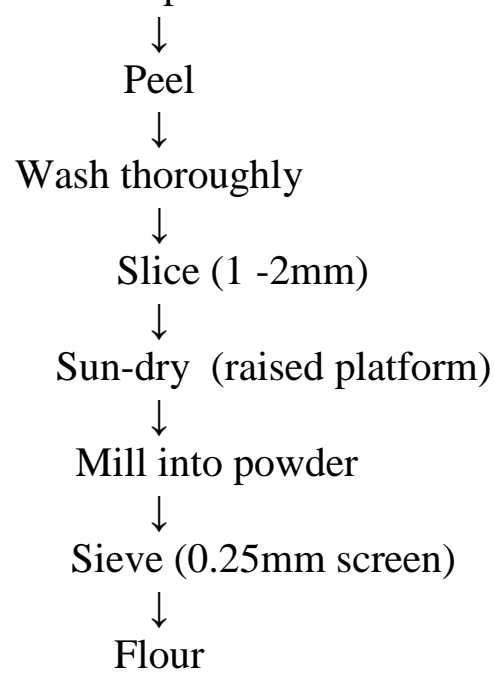

Figure: 1

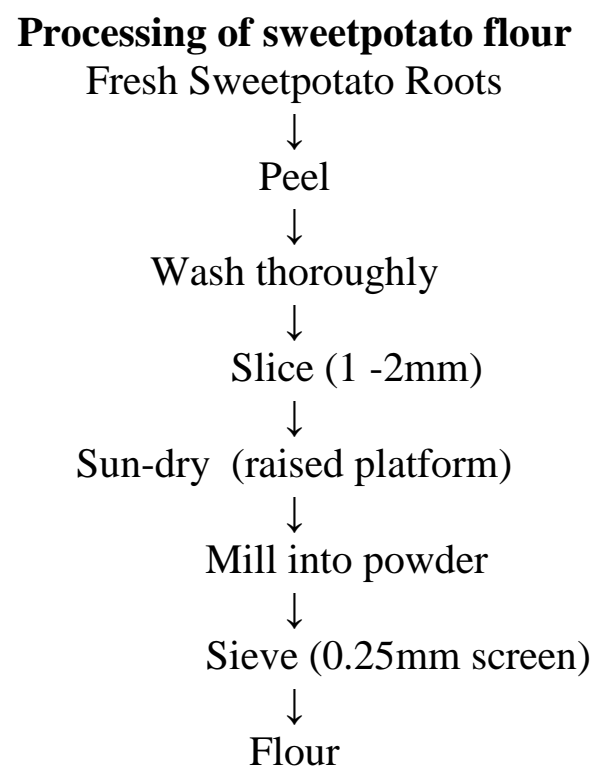

Figure: 2

Proximate analysis - The proximate composition of the Hausa-potato bread samples (HPBs), sweetpotato bread samples (SPBs) and wheat bread samples (WHBs) were determined using the AOAC methods as described by (Onimawo and Egbekun, 1998). The samples were analyzed for moisture, ash crude fiber, crude protein, crude fat and carbohydrate (by difference).

Sensory evaluation - The sensory attributes, (colour, texture/mouth feel, taste and general acceptability) were evaluated by a 20 -member panel of judges, using a 7-point Hedonic scale 
with 1 representing the least score (dislike, extremely) and 7 the highest score (liked, extremely).

Statistical analysis - Analysis of variance (ANOVA) was performed on the data gathered using a statistical analytical system (SAS, 1999 version) to determine differences while Least Significant Difference (LSD) was used to detect significant differences among the means.

\section{RESULTS AND DISCUSSIONS}

The proximate composition of the hausa-potato bread samples, sweetpotato samples and the wheat bread (control) are presented in Table 1. Low protein content was observed with the hausa-potato and sweetpotato bread samples compared to the wheat bread sample. This could be as a result of the low protein content which root and tuber crops are known for (Rowland, 1993). The protein contained in sweetpotato bread samples was slightly higher than that in Hausa-potato.

Table 1: Proximate composition of Hausa-potato bread, sweetpotato bread and wheat bread samples

\begin{tabular}{|c|c|c|c|c|c|c|}
\hline $\begin{array}{l}\text { Bread } \\
\text { samples }\end{array}$ & $\begin{array}{c}\text { Protein } \\
(\%)\end{array}$ & $\begin{array}{l}\text { Crude } \\
\text { fiber } \\
(\%)\end{array}$ & $\begin{array}{l}\text { Ether } \\
\text { extract } \\
(\%)\end{array}$ & $\begin{array}{l}\text { Ash } \\
(\%)\end{array}$ & $\begin{array}{l}\text { Moistur } \\
\text { e }(\%)\end{array}$ & $\begin{array}{l}\text { Carbohydrat } \\
\text { e }(\%)\end{array}$ \\
\hline $\mathrm{A}$ & 6.78 & 0.22 & 0.75 & 1.0 & 31.02 & 60.23 \\
\hline B & 2.45 & 3.56 & 2.70 & 0.91 & 36.50 & 53.88 \\
\hline $\mathrm{C}$ & 2.45 & 3.30 & 2.43 & 0.89 & 35.64 & 55.29 \\
\hline D & 2.44 & 3.21 & 2.40 & 0.8 & 33.40 & 57.75 \\
\hline E & 2.74 & 1.50 & 2.53 & 0.89 & 35.78 & 56.56 \\
\hline $\mathrm{F}$ & 2.72 & 1.37 & 2.46 & 0.85 & 35.10 & 57.50 \\
\hline $\mathrm{G}$ & 2.70 & 0.85 & 2.43 & 0.8 & 34.09 & 59.13 \\
\hline
\end{tabular}

A -bread produced from 100\% wheat flour; B- bread produced from $30 \%$ Hausa-potato composite flour; C- bread produced from 20\% Hausa-potato composite flour; D- bread produced from $10 \%$ Hausa-potato composite flour; E- bread produced from $30 \%$ sweetpotato composite flour; F- bread produced from $20 \%$ sweetpotato composite flour; G- bread produced from $10 \%$ sweetpotato composite flour.

Table 2: Sensory mean scores of the Hausa-potato and Wheat bread samples

\begin{tabular}{c|llll}
\hline Samples & \multicolumn{4}{c}{ Sensory Attributes } \\
\hline & Colour & Taste & Texture & General acceptability \\
\hline A & 6.5 & 6.5 & 6.4 & 6.5 \\
B & 4.4 & 5.1 & 4.9 & 4.7 \\
C & 4.9 & 5.7 & 5.2 & 5.2 \\
D & 6.1 & 6.0 & 5.9 & 6.2 \\
\hline LSD & $\mathbf{0 . 4 8}$ & $\mathbf{0 . 8 8}$ & $\mathbf{0 . 7 0}$ & $\mathbf{0 . 6 8}$ \\
\hline
\end{tabular}

A $-100 \%$ wheat bread; B-30\% Hausa-potato bread supplement; C-20\% Hausa-potato bread supplement; D- 10\% Hausa-potato bread supplement. 
Table 3: Sensory mean scores of the Sweetpotato and Wheat bread samples

\begin{tabular}{l|llll}
\hline \multicolumn{1}{c|}{ Samples } & \multicolumn{5}{c}{ Sensory Attributes } \\
\hline & Colour & Taste & Texture & General acceptability \\
\hline A & 6.5 & 6.5 & 6.4 & 6.5 \\
B & 5.9 & 5.1 & 4.9 & 5.0 \\
C & 5.2 & 4.5 & 5.4 & 5.2 \\
D & 5.5 & 5.6 & 5.4 & 6.2 \\
\hline LSD & $\mathbf{0 . 5 0}$ & $\mathbf{0 . 6 2}$ & $\mathbf{0 . 6 8}$ & $\mathbf{0 . 5 7}$ \\
\hline A $-100 \%$ & bread; B-30\% & sweetpotato bread supplement; C-20\% & sweetpotato bread \\
\multicolumn{5}{c}{ supplement; D- 10\% sweetpotato bread supplement }
\end{tabular}

Highest ash content of $1.0 \%$ was recorded with the wheat bread sample. However, there were no significant $(\mathrm{P}<0.05)$ differences in ash content of wheat bread and the other bread samples of hausa-potato and sweetpotato in almost all the substitution levels. The ash content increased with progressive increase in wheat flour content of the other samples.

It is interesting to note that the crude fiber obtained for the hausa-potato was higher than wheat bread and sweetpotato bread samples, implying that Hausa-potato is rich in crude fiber. In addition to other importance of fiber in food, it helps to reduce the level of LDL (Low Density Lipoprotein) cholesterol in blood (Felicity and Maurica, 1992). The fat content of bread produced from hausa-potato bread, sweetpotato bread and wheat bread samples ranged from 0.75 to 2.7 with the highest fat observed in hausa-potato bread at $30 \%$ substitution level. A progressive increase in fat content was observed as the substitution levels of hausa-potato and sweetpotato increased.

The mean sensory evaluation scores obtained for the bread samples of wheat and Hausa-potato ranges from 4.4 to 6.5 (Table 2). The (ANOVA) shows that the wheat bread did not differ significantly from $10 \%$ hausa-potato bread samples at $(\mathrm{p}<0.5)$, in the sensory attributes of taste, colour, texture and general acceptability. However, at higher substitution levels of Hausa-potato flour $(20 \%$ and $30 \%)$, varying significant differences were observed with the bread samples in comparison with the wheat bread in all the attributes tasted at the same probability level.

On the other hand, the mean sensory evaluation of sweetpotato and wheat samples ranges from 4.5 to 6.5 (Table 3). At 20 and $30 \%$ substitution levels sweetpotato bread samples were significantly $(\mathrm{P}<0.05)$ different in some of the attributes tested (colour, taste, and texture) from the wheat bread with wheat bread being preferred by the panelists. However, at $10 \%$ substitution level there was no significant $(\mathrm{P}<0.05))$ difference in the general acceptability of wheat bread and sweetpotato bread. The preference of wheat bread to sweetpotato bread samples notwithstanding, in general acceptability all the samples of sweetpotato bread were acceptable by the panelists. The ranking test conducted reveals that the wheat bread was ranked higher in all the attributes. However, this does not mean that other bread samples were not acceptable, even at 30\% substitution level the panelists seem to like the taste and colour of bread produced from sweet potato. The higher ranking for wheat bread could be due to the familiarization of the consumers to the normal wheat bread (Olaoye et al, 2006).

Finally, in all the attributes tasted bread produced from $10 \%$ hausa-potato sample was not significantly different from the wheat bread sample which lends credence to the use of $10 \%$ Hausa potato supplement in bread production. Also, 10\% sweetpotato did not show any significant difference in general acceptability from wheat bread. 


\section{CONCLUSION}

Based on the findings, we therefore recommend the use of sweetpotato and hausa-potato flour as a composite (10-30\%) to wheat flour in bread production. There is need for further research on improving the nutrient quality especially protein level of bread produced from these sources.

\section{REFERENCES}

Allenmann, J. and Coertze, A.F. (1997). Indigenous Root Crops. A.Z Plectranthus. Pretoria, South Africa; Vegetable and Ornamental Plant Institute.

Aniedu, C and Oti E (2007). Sweet Potato Based Recipes. Extension bulletin. National Root Crops Research Institute, Umudike.

Edema M.O, Sanni.O, and Sanni A.I (2005). Evaluation of Maize - Soybean Flour Blends for Sour Maize Bread Production in Nigeria. Afr. J Biotechnol.4 (9):911-918.

Felicity S.K and Ann B (1992). Nutrition for Developing Countries. Second Edition. PP11

Giami S.Y, Amasisi T,Ekiyor G (2004). Comparison of Bread Making Properties of Composite Flour from Kernies of Roasted and Boiled African Breadfruit (Treculia Africana decne) Seeds. J.Mat.Res. 1(1):16-2

Kay, D.E (Revised by Gooding, E.G.B) (1987). Crop and Product Digest No 2- Root Crops, second Edition. London: Development and Research Institute, xv $380 \mathrm{Pp}$.

Olaoye O.A, Onilude A.A and Idowe O.A (2006). Quality Characteristics of Bread Produced from Composite Flours of Wheat, Plantain and Soybeans. Afri. J. Biotechnol. 5(11), pp 1102-1106.

Onimawo A.I and Egbekun K.M (1998). Comprehensive Food Science and Nutrition. Revised edition. Pp 193 - 203

Rowland J.R.J (1993). Dry Land Farming in Africa page 263 - 284. 